\title{
DESFILES, RAINHAS E DANÇA: MANIFESTAÇÕES NEGRAS COMO ESPAÇO DE REIVINDICAÇÕES E AFIRMAÇÃo
}

\author{
Raphael Rodrigues Vieira Filho (UNEB)*
}

\section{RESUMO}

Nas últimas décadas, as manifestações populares vêm se fortalecendo no âmbito social e, também, como campo de pesquisas acadêmicas, principalmente na área de Ciências Humanas. O campo da Educação tem se interessado e produzido pesquisas envolvendo manifestações populares, e muitos pesquisadores têm utilizado pensadores pós-coloniais como base dos trabalhos. Esse texto se insere nesta linha, procurando analisar manifestações culturais negras como espaço de crítica social, reivindicação e afirmação negra. As fontes utilizadas foram colhidas de jornais diários e bibliografia de época sobre Salvador, BA, do final do século XIX até a metade do XX. Os dados e informações foram organizados com base nas fichas de leitura e transcrições, e foram analisados seguindo a metodologia de análise documental. As manifestações culturais negras trazem em seu bojo aspectos de uma tradição seletiva, mas também aspectos incorporados ou adaptados, promovendo uma intrincada rede de signos. Percebemos, nas reivindicações, indicadores de um confronto com as autoridades e elites ao longo do tempo, além da construção e fortalecimento de ser negro. Este artigo é a primeira sistematização de dados de uma pesquisa sobre manifestações culturais em Salvador e aponta para a importância de ampliarmos os dados para as várias formas de transmissão de conhecimentos dessas manifestações, podendo assim contribuir com dados para pesquisas nas mais diversas áreas do conhecimento.

Palavras-chave: Manifestações culturais. Resistência. Negros. Carnaval.

\section{ABSTRACT}

\section{PARADES, QUEENS AND DANCE: BLACK MANIFESTATIONS AS A SPACE OF REIVINDICATION AND AFFIRMATION}

In the last decades the popular manifestations have been strengthening in the social scope and also as a field of academic research mainly in the areas of Human Sciences, in addition, many of the researchers dedicated to the subject are linked to these manifestations and often use thinkers the basis of the work.

\footnotetext{
* Doutor em História Social pela Pontifícia Universidade Católica de são Paulo (PUC-SP). Pós-doutor em História e Política pela Università di Padova, Itália. Professor Titular Pleno do Departamento de Educação (DEDC) Campus I Salvador, Professor do Programa Pós-Graduação em Educação e Contemporaneidade (PPGEduC) e Professor do Programa de Pós-Graduação em Estudos Africanos, Povos Indígenas e Culturas Negras (PPGEAFIN) da Universidade do Estado da Bahia (UNEB). E-mail: raphafilho@gmail.com
} 
This text is inserted in this line, it tries to analyze black cultural manifestations as space of social critique, claim and black affirmation. The sources of research are news from daily newspapers and period bibliography. Content analysis and contextualisation were used. Black cultural manifestations bring in their aspects aspects of a selective tradition, but also incorporated or adapted aspects promoting an intricate network of signs. We perceive, in the claims, indicators of a confrontation with the authorities and elites over time, as well as the construction and strengthening of being black.

Keywords: Cultural manifestations. Resistance. Blacks. Carnival.

\section{RESUMEN}

\section{DESFILES, REINAS Y DANZA: MANIFESTACIONES NEGRAS COMO ESPACIO DE RECLAMACIONES Y AFIRMACIÓN}

En las últimas décadas, las manifestaciones populares se vienen fortaleciendo en el ámbito social y, también, como campo de investigaciones académicas, principalmente en el área de Ciencias Humanas. El campo de la Educación se ha interesado y producido investigaciones que involucran manifestaciones populares y muchos investigadores han utilizado pensadores postcoloniales como base de los trabajos. Este texto se inserta en esta línea, buscando analizar manifestaciones culturales negras como espacio de crítica social, reivindicación y afirmación negra. Las fuentes utilizadas fueron recolectadas de periódicos diarios y bibliografía de época sobre Salvador, BA, desde el final del siglo XIX hasta la mitad del XX. Los datos e informaciones se organizaron sobre la base de las fichas de lectura y transcripciones, y se analizaron siguiendo la metodología de análisis documental. Las manifestaciones culturales negras traen en su seno aspectos de una tradición selectiva, pero también aspectos incorporados o adaptados, promoviendo una intrincada red de signos. En las reivindicaciones, percibimos indicadores de un enfrentamiento con las autoridades y elites a lo largo del tiempo, además de la construcción y fortalecimiento de ser negro. Este artículo es la primera sistematización de datos de una investigación sobre manifestaciones culturales en Salvador y apunta a la importancia de ampliar los datos para las diversas formas de transmisión de conocimientos de esas manifestaciones, pudiendo así contribuir con datos para investigaciones en las más diversas áreas del conocimiento.

Palabras clave: Manifestaciones culturales. Salvador. Resistencia. Negro. Carnaval.

\section{Introdução}

Nas últimas décadas as manifestações populares vêm se fortalecendo não só como atividades lúdicas de jovens e adultos, mas também como um campo fértil de pesquisas acadêmicas de todas as áreas. Antropólogos, sociólogos, linguistas e educadores têm se apropriado das festas populares, seus temas e organizações como objetos de estudos. Os estudos passam a fugir da folclorização e descrição realizada por pessoas externas a manifestações e expressões culturais e passam a ser narradas, lidas, historicizadas e analisadas de dentro, ou pelo menos com um olhar mais próximo e propício. 
Beneficiada pelas propostas metodológicas e historiográficas da Nova História Cultural e trazendo trabalhos com foco em locais antes deixados de lado, e parcelas da população sem voz e visibilidade, essa nova forma de ver os objetos de estudos e os teóricos utilizados como base criticam os cânones eurocêntricos e os valores instituídos na Academia de distanciamento - garantidor do rigor científico - e bases teóricas construídas para análises de conjunturas eurocêntricas.

Questões como gênero, raça, etnicidade, religiosidade, identidade, entre outras, passam a ser tema central na construção de objetos de pesquisa. Talvez impulsionados pela máxima: "Toda história é 'história contemporânea' [...]", elaboração de Edward Hallett Carr (1982 p. 21), com base na leitura de Benedetto Croce, assim os temas escolhidos pelos pesquisadores estão sempre contaminados pelo seu tempo, expressando suas preocupações e o contexto do agora.

\section{0 trabalho do historiador e a colaboração com outras áreas de conhecimento}

O trabalho do historiador, dessa forma, “[...] consiste essencialmente em ver o passado através dos olhos do presente e à luz de seus problemas [...]" (CARR, 1982 p. 22). Permeados pelas discussões de inclusão e dos movimentos questionadores do eurocentrismo - alguns desses autores identificados com o pós-colonialismo -, e muitas vezes militantes desses movimentos, novos pesquisadores trazem problemas antes não tocados pela História das manifestações culturais.

E nós, das Ciências Humanas e pesquisadores "[...] da cultura popular, devemos sempre começar por aqui: com o duplo interesse da cultura popular, o duplo movimento de conter e resistir, que inevitavelmente se situa em seu interior." (HALL, 2003, p. 249).

Afinal, como afirma Homi K. Bhabha (1998, p. 240), “[...] toda uma gama de teorias críticas contemporâneas sugere que é com aqueles que sofreram o sentenciamento da história - subjugação, dominação, diáspora, deslocamento - que aprendemos nossas lições mais duradouras de vida e pensamento." Assim os sujeitos pós-modernos (HALL, 2006) são contemplados.

0 Carnaval é propalado como uma das festas mais comemoradas em todo o ocidente, incluindo os lugares que tiveram a experiência de sua colonização europeia. Em várias partes do mundo a indústria do turismo utiliza como atrativo as diversas e variadas formas de comemorar o Rei Momo. Na Bahia, desde pelo menos 1911, em Salvador, e depois transferido para outras partes do interior e até mesmo para fora do estado, também temos as Micaretas - ou Carnaval fora de época - em dias posteriores ou até anteriores ao Carnaval.

No senso comum, até em textos de alguns acadêmicos mais antigos, as festas momescas são divulgadas como as verdadeiras festas populares e democráticas, porém em diversas oportunidades na história dessas festas vemos as elites tentando apropriar-se dos principais elementos populares em seus divertimentos e expulsar das ruas os grupos populares não enquadrados nos moldes desejados pelos organizadores e financiadores das festas, as elites sempre pensando em valorizar o momento das festas e reserva-lo para aqueles que podem pagar por ela.

As festas momescas nos últimos anos têm atraído multidões. Os pequenos blocos ganham as ruas de cidades onde ou não existiam, ou eram negligenciados pelas autoridades. Em cidades com São Paulo e Rio de Janeiro, que em passado recente só eram importantes para a grande imprensa as Escolas de Samba, agora revivem os tempos do Blocos de Rua, contentando todos os gostos musicais. Festas contidas entre arquibancadas, ou em cidades menores sem uma grande tradição, tornaram-se objeto de atração turística, gerando renda e riqueza, ganham os espaços da rua em ciclo colorido, maravilhando espectadores presentes e on-line (BUENO, 2006). 
As manifestações festivas dedicadas a Momo têm sua origem bastante controversa e as diversas argumentações sobre legitimidade e origem transformam as discussões em ponto de honra. Muitos estudiosos afirmam serem festas populares europeias introduzidas talvez no século XI; esta versão leva essas brincadeiras ao status de mais antigas da cultura ocidental e, também, com o mais longo histórico de ocorrências no tempo. Alguns estudos ligam as brincadeiras carnavalescas à tradição cristã - sem descartar as reminiscências de festas de colheitas comemoradas desde o continente africano com os egípcios, passando pelos Festivais em homenagem a Baco, as saturnais e lupercais -, enquanto outros procuram analisar a festa como uma expressão cultural com contornos e dinâmicas próprias, analisando cada festa como um fenômeno único encerrado nele mesmo, embora com historicidade e longevidade inegáveis (SOIHET, 1999).

Dois detalhes chamam atenção e ligam as festas momescas da atualidade à pós-modernidade:

a) a cobertura midiática das festas carnavalescas - emissoras de televisão e rádio dedicam várias horas de transmissão ao vivo das festas; além de algumas manterem programas dedicados à música, dança e fomentadores das festas, jornais diários e revistas também contribuem com essa cobertura;

b) um dos mais fortes traços da pós-modernidade é a transformação em mercadoria do que antes fazia parte do cotidiano. Portanto, a transformação das festas momescas retroalimentam a midialização e esse fenômeno valoriza cada vez mais alguns lugares que promovem as festas como atração turística, gerando lucros. Tudo se interliga, se mistura e se complementa, outra característica da pós-modernidade: nada é simples e tudo está interligado (SANTOS, 1986).

As manifestações festivas das populações negras - com músicas, danças e as algazarras pertinentes - tinham como espaço tradicional os átrios das Igrejas Católicas nos dias de festas religiosas, de onde foram expulsas, em meados do século XIX, com a romanização promovida pela Igreja Católica (VERGER, 1980). Com isso as manifestações de cunho mais teatral e solene, em algumas partes do Brasil, ficaram restritas ao Carnaval e ao chamado ciclo de Reis - período entre a Ascensão e a Festa de Cristo Rei. Para as mais barulhentas e libidinosas, as restrições foram maiores, sobrando somente os períodos das festas Momescas para essas expressões festivas.

Desde o final do século XIX, as elites dirigentes tentaram sem êxito extirpá-las das ruas também nos dias de carnaval, gerando diversas formas de resistência e transformando as festas dedicadas a Momo em local de confronto e reivindicação de espaço e de outras propostas para a vivência na cidade. Nossas pesquisas são uma forma de tornar público as várias maneiras, utilizadas desde o século XIX pelas populações negras, de manifestar seus pensamentos, informar suas intenções e fazer suas reivindicações em um dos únicos espaços possíveis para isso: as festas dedicadas ao Rei Momo.

Identificamos, nesta fase da pesquisa sobre os processos de construção e propagação de conhecimento em manifestações culturais, uma importante transmissão de aprendizagens nessas brincadeiras ligadas à tradição - como processo de conservação, difusão de memórias e valorização de aspectos caros para as comunidades negras -, mas também de processos de apropriação do novo: formas de brincar, novas estéticas, novos materiais utilizados na elaboração de alegorias, novas informações difundidas, novas formas de educar e multiplicar conhecimentos. Portanto, este texto é a sistematização de informações importantes, mas que não se esgota aqui, ficando uma segunda fase da pesquisa dedicada somente aos processos formativos e de transmissão do conhecimento, que agora não pudemos explorar.

Utilizamos neste trabalho informações retiradas de notas e reportagens presentes em jornais diários e bibliografia de época sobre Salvador (BA), do final do século XIX até a metade do século XX. Os dados e informações 
foram organizados com base nas fichas de leitura e transcrições, e foram sistematizados e analisados seguindo a metodologia de análise documental.

\section{Festas populares e carnaval: algumas notas históricas}

Olga Rodrigues de Moraes von Simson (1981), preocupada em desmistificar a ideia, reinante na historiografia, de que o carnaval brasileiro sempre foi uma festa popular e democrática, retomou as pesquisas históricas sobre o tema em diversos trabalhos. Utilizando informações colhidas em suas pesquisas e em trabalhos de colegas, estabeleceu três grandes fases para a história do carnaval brasileiro:

a) Da época colonial até 1850 - Período do carnaval de estilo lusitano, com predominância do entrudo em todas as principais cidades brasileiras;

b) De 1850 a 1920 - Período do Carnaval Veneziano ou Burguês. Sua principal característica eram os desfiles das grandes sociedades, fundadas geralmente por rapazes da elite. Primeiro faziam os bailes de máscaras e depois os préstitos com ricos trajes e em carruagens ricamente decoradas. Nessa fase também aconteceu o declínio do entrudo, taxado de brincadeira incompatível com as cidades civilizadas. As camadas populares limitavam-se a assistir aos desfiles das grandes sociedades, num primeiro momento, e, mais para o final do período, buscavam nas suas tradições forjar divertimentos alternativos;

c) De 1920 aos nossos dias - Período de Afirmação do Carnaval Popular, tendo como principal característica os desfiles das escolas de samba. Segundo essa autora, a afirmação do carnaval popular ocorreu graças aos embates das camadas populares com as dirigentes, que só mediante algumas imposições e restrições admitiram-nas em seu espaço "civilizado"; desta forma as manifestações lúdicas populares fizeram várias concessões e tiveram que se "[...] dobrar a uma regulamentação estrita e à transformação de sua manifestação lúdica numa mercadoria passível de ser comercializada." (SIMSON, 1981, p. 305).
Pelas pesquisas realizadas é possível afirmar que em todas essas fases as populações negras estiveram presentes, fizeram parte das festas e procuraram transformar suas condições de vida introduzindo solicitações ou críticas em suas manifestações festivas. Vejamos alguns desses momentos.

A famosa Scene De Carnaval, produzida por Jean B. Debret (1972, p. 33), retrata as brincadeiras típicas da primeira fase do carnaval com predominância do Entrudo. É possível ver uma mulher negra ganhadeira sendo pintada por um rapaz negro, ambos eram molhados por um menino. Observa-se também uma vendedora de laranjinhas, objeto feito de cera contendo líquidos diversos no seu interior, um comprador desses objetos, e também é possível observar outras pessoas negras escondidas da sanha dos brincantes.

Debret (1972) também retratou a desigualdade no homem que tenta pintar a mulher ganhadeira com um sorriso no rosto, e ela, assustada, equilibrando sua mercadoria na cabeça para evitar o prejuízo da Quebra da Guia $^{1}$ e ainda tentando se desvencilhar do agressor. Um outro homem, em uma das portas do estabelecimento, está com uma laranjinha em posição de arremesso na direção da mesma mulher que já está sendo agredida. Ficamos com a impressão de que mais importante que manter o rosto limpo é não perder a mercadoria, que garantia o sustento, ou com o prejuízo não ter o dinheiro de pagamento do dia ao seu senhor ou senhora.

Outro ponto importante é observar os processos de transmissão dos conhecimentos postos na Cena do Carnaval: um menino vende alguma coisa na porta do estabelecimento e outro já está brincando com um espirrador. Todavia, por outras fontes é possível questionar Debret; talvez ele tenha pintado muito mais do que realmente acontecia. Aos negros “[...]

1 É como se diz, no mercado informal, quando um vendedor perde sua mercadoria e assim fica sem condições de sobrevivência. É uma analogia às religiões afro-brasileiras, quando o adepto perde a proteção no momento em que o colar de seu Santo é quebrado. 
cabia abastecer seus senhores com a água e a fabricação de 'laranjinhas', ou ser a principal vítima dos filhos das elites nas ruas. Eles também brincavam molhando as escravas nas alamedas e perto das fontes." (VIEIRA FILHO, 1997, p. 39).

Outra possibilidade para as populações negras nesse período eram os batuques e as rodas de samba. Esses divertimentos aconteciam em diversos espaços de Salvador pelo menos desde o século XVIII. Eles eram classificados pelas elites de acordo com a origem étnica dos seus participantes, e eram mais ou menos permitidos de acordo com essa classificação (SANTOS, 1997).

Os questionamentos sobre o lugar e período de festejar, assim como as estratégias para burlar as proibições dos párocos nas festas religiosas, talvez seja o primeiro embate enfrentado pelos grupos negros organizadores de manifestações festivas. Em muitas festas de Santos e Irmandades os batuques e sambas resistiram e foram absorvidos nas comemorações oficiais, ludibriando os preceitos da romanização. No final do século XX, com a introdução de modificações formais nas celebrações de missas e outras atividades da Igreja Católica, as manifestações lúdicas negras voltam com força e são revalorizadas (SANTOS FILHO, 2012).

Voltando às celebrações das festividades dedicadas ao Rei Momo, os documentos trouxeram informações preciosas sobre outras formas de reivindicação bastante expressivas e explícitas acontecidas na segunda fase apontada por Olga Von Simson. Trata-se da solicitação de indenização presente no primeiro item do Manifesto Carnavalesco do Clube Uniformizado Negro Embaixada Africana, publicado no Jornal Correio de Notícias de 27 de fevereiro de 1897: "[...] 10 Instituir sobre o Estado Federado da Bahia o Mucamo de 592185071824197012709 2160257363280 de jardos de algodão riscado, como indennisação pelos africanos mortos no mesmo estado, por occasião do movimento alcunhado de levantamento de malês" (MANIFESTO..., 1897, p. 2).
O manifesto, assim como os demais itens do desfile, foi copiado do programa entregue pelo próprio clube aos jornais, portanto refletem as atitudes do clube, ou pelo menos de seus dirigentes e principais fomentadores. Então nossa primeira chave de leitura e análise parte do próprio nome do grupo: Embaixada Africana. A tradicional forma de préstitos afro-brasileiros representando embaixadas, ou o encontro de cristãos com outras de mouros, é no manifesto recordada.

A apropriação de elementos tradicionais para a formação de uma nova manifestação foi assim comentada por Raymond Williams (1978, p. 118):

O que temos de ver não é apenas uma tradição, mas uma tradição seletiva: uma versão intencionalmente seletiva de um passado modelador e de um presente pré-moldado, que se torna poderosamente operativo no processo de definição e identificação social e cultural.

Reisados, Maracatus, Taieiras, Cacumbi, Ticumbi, Marujadas, Congadas e outras representações lúdicas apresentam elementos muito parecidos em sua organização festiva. Contudo, as tradições se misturam, se complementam e se ressignificam. Assim, elementos centrais em uma manifestação aparecem como secundários ou nem mesmo são citados em outras. As escolhas são históricas, seletivas e às vezes estéticas em cada uma das expressões e na mesma agremiação ao longo do tempo.

No Manifesto do Clube Embaixada Africana, diversos elementos são pinçados de vários locais, impérios e reinos africanos, dando um ar de diversidade e multiplicidade, citados no mesmo documento: a banda de música vestida com "[...] notavel costume algeriano [...] Guerreiros Reaes Cafres - Zulos [e] cavalgando animal alexandrino o embaixador Manikus, ladeado pelo Muata de T'Chiboco [...]" (MANIFEST0..., 1897, p. 2).

Os Guerreiros Cafres são conhecidos na literatura colonial como os mais belicosos e destemidos de toda a África. Eles resistiram tanto ao controle de sua região pelos bôeres 
quanto pelos britânicos em sua expansão no sul do continente africano. Os bôeres eram descendentes de colonos calvinistas, na sua maioria holandeses, que ocuparam territórios ao longo do rio Vaal, que posteriormente se tornaria parte do Transvaal, um estado independente anexado pelos britânicos em 1877 que, em 1881, garante sua independência.

No momento do desfile do Embaixada Africana, a região era disputada nos campos diplomáticos, mas já havia sido travada uma primeira fase - de dezembro de 1880 a março de 1881 - do que ficou conhecido como Guerra do Bôeres, que em sua segunda fase durou de outubro de 1899 a maio de 1902.

Não encontramos nenhuma referência sobre o embaixador Manikus, mas parece que os organizadores do Embaixada Africana agora estão brincando com os leitores, pois Manikus pode ser uma forma corrompida de manibus, mão em latim. Muata é uma palavra iorubá e quer dizer primeiro, enquanto T'Chiboco é uma região de Lunda, Angola, visitada pelo celebre etnógrafo José Redinha (1953).

O Carnaval proporciona esses momentos de descontração, mas a brincadeira era para quem conhecia as referências. Guerreiros do sul da África, uma palavra iorubá e uma referência à região de Angola, tudo compondo um programa de desfile carnavalesco. Os brincantes da Embaixada Africana detinham um conhecimento panorâmico do continente africano que, com toda certeza, devia ter sido transmitido pelos mais velhos, que ficavam na retaguarda da brincadeira, mas na ponta de lança da sabedoria.

Segundo as estatísticas de Nina Rodrigues (1988, p. 109), Salvador contava com cerca de 2000 africanos em 1896; o número é pequeno, mas não desprezível. Esses homens e mulheres devem ter transmitido seus conhecimentos e experiências para os mais jovens, além disso, muitos desses negros tiveram acesso à educação formal e podem ter contribuído de alguma forma para a transmissão dos conhecimentos necessários para formular o roteiro do Embaixada Africana.
Mostrar uma erudição sobre si, falando de coisas conhecidas somente pela comunidade de africanos e seus descendentes, também era uma maneira de destacar uma ilustração enciclopédica sobre o continente e sobre o que se passava naquele momento na África. As informações podem ter chegado ao Porto de Salvador com os marinheiros que iam e vinham da África. Em pesquisa anterior, constatamos uma constante movimentação de navios em anos próximos ao desse desfile (VIEIRA FILHO, 1995).

O pedido de indenização pelos africanos mortos na Revolta dos Malês, ocorrida em 1835, e ainda por todos os prejuízos morais causados pelos açoites, recebidos pelos africanos, em praça pública, talvez seja a peça mais fácil na leitura e sem dúvida uma das mais intrigante do quebra-cabeça.

Os participantes dessa revolta foram castigados exemplarmente pelas elites soteropolitanas, alguns pagando com a própria vida, outros punidos com castigos menores, como açoites em praça pública, mas todos os negros habitantes de Salvador foram punidos, pois a partir dessa revolta ficaram proibidos todos os tipos de reuniões, inclusive as lúdicas, conforme podemos observar nas várias posturas publicadas depois de 1835 (SALVADOR, 1988).

0 montante exorbitante da solicitação era uma forma de denunciar o elevado custo de vida, que com toda certeza era muito mais prejudicial aos negros soteropolitanos que para as elites. Também pode significar a indenização pelos outros aspectos da vida social das populações negras, que foi desorganizada com a repressão posterior à Revolta dos Malês. A proibição de reuniões afetava as formas de religiosidade, as brincadeiras, as convivências e as trocas de experiências e de informações, mas com toda certeza essas proibições foram burladas, é só ler as várias reedições das proibições para saber isso.

A Revolta dos Malês foi considerada pelos componentes do Embaixada Africana uma revolta justa; o injusto para eles foi a escravi- 
zação dos africanos sem nenhuma base jurídica plausível. Consideravam a escravidão injusta, porque as raças eram iguais em sua inteligência e em seu potencial, desarticulando desse modo as teorias racistas que colocavam as raças negra e amarela como inferiores, portanto passíveis de escravidão; assim as ideias racistas eram combatidas no momento de sua maior influência sobre os intelectuais brasileiros.

Na Nota contendo o Programa do Clube Uniformizado Negro Embaixada Africana do Carnaval de 1898, publicado no Jornal de Notícias de 19 de fevereiro de 1898, lemos o seguinte:

[...] Como prova de que a civilisação não é uma utopia no continente negro (como propalam os maldizentes) seguir-se-ha bem organisada Banda de Musica [...] 0 Carro de Madre Pérola. Possuidos do louvavel desejo de anniquilar os detractores do grande paiz de Cham, os mesmos africanos prepararam por suas proprias mãos o interior desse carro, podendo-se assim avaliar o gráo de adeantamento a que tem attingido $\mathbf{A}$ Arte Africana. (O CARNAVAL, 1898, p. 1, grifo do autor).

0 combate às ideias preconceituosas era direto e franco. Sem subterfúgios, os organizadores do Clube Uniformizado Negro Embaixada Africana falavam francamente contra as ideias do racismo científico, mostrando nas festas de Momo ser possível fazer um desfile rivalizando com os grandes clubes da elite, preparando com as próprias mãos um carro utilizando todo o conhecimento dos artífices africanos e dos seus descendentes aqui instalados.

Os argumentos utilizados pelo programa do Embaixada são forjados a partir de referências europeias: o carro de madrepérola foi importado, somente seu acabamento final foi dado pelos africanos da Embaixada, mas com certeza foram utilizados modelos europeus nessa decoração. Outro aspecto dessa questão é o fato de o progresso material alcançado pela belle époque exercer um fascínio tal sobre outras civilizações, tornando-se uma referência de progresso desejável.

Os elementos europeus nos desfiles dos clubes uniformizados indicam também as conces- sões e negociações simbólicas, utilizadas pelos grupos negros para preservarem muitas características africanas em seus préstitos. Dessa forma, eram utilizados elementos brancos para dar a aparência de desfiles europeus, enquanto eram preservados os instrumentos; os cantos, em línguas africanas; os ritmos; as vestes e outros elementos africanos e afro-brasileiros.

Essa preocupação em destacar a habilidade dos africanos para decorar o carro com o mesmo luxo e cuidado dos carros dos clubes uniformizados brancos, importados da Europa, teve a intenção de mostrar a capacidade para a civilização dos negros fomentadores dos desfiles do clube uniformizado negro. Também demonstram formas de transmissão de conhecimento e apuro de habilidades presentes na comunidade negra naquele momento.

Tudo indica que o Carnaval era a vitrine para mostrar os dons, os esmeros e caprichos dos negros. Essa exposição de talentos devia ser recompensada com a contratação desses artistas habilitados e experientes nas decorações estilo europeu para trabalhos posteriores aos momentos lúdicos para a população de forma geral, mas especialmente para as elites que estavam, neste momento, deixando as velhas casas do Pelourinho e adjacências para se instalar nos casarões da Vitória.

Temos ainda, nos manifestos dos grupos uniformizados negros, a tática de utilizar elementos de culturas florescentes na África, reconhecidas como adiantadas em progressos técnicos. As referências aos mouros, egípcios e etíopes são as mais utilizadas. Os primeiros dominaram a Península Ibérica por séculos, os segundos intrigam até hoje os estudiosos por suas técnicas avançadas de grandes construções e os últimos foram os mais resistentes às investidas do colonialismo europeu, fazendo frente às várias tentativas de invasão pelos italianos, no século XIX.

Foram as formas de combate ao racismo conservadas na documentação pesquisada, mesmo porque os periódicos eram o meio de comunicação privilegiado para a propaganda 
do racismo naquele momento, e a principal tribuna dos intelectuais racistas, para expressarem suas ideias.

Outro elemento importante nessa forma de manifestação lúdica das populações negras são as críticas às formas como eram conduzidos os serviços públicos na cidade. Foi encontrada a transcrição de um telegrama no Correio de Notícias do dia 18 de fevereiro de 1898:

[...] Desejando os africanos aqui residentes dar uma prova de apreço a esses patricios, mandaram fabricar na França um lindo carro de madreperola para transportal-os, o qual, tendo chegado em agosto, ainda se acha na alfandega, graças á actividade desta repartição. (RECLAMAÇÕES, 1898, p. 2).

Os organizadores do Clube Uniformizado Negro Embaixada Africana criticam a forma como a alfândega da cidade funcionava e assim todo o serviço público era colocado em xeque. As críticas, ao longo do tempo, também recaem sobre o serviço de iluminação, de transportes, serviço de higiene e outros.

A desaprovação aos serviços públicos oferecidos à população chegou ao ponto de todos os clubes uniformizados utilizarem um carro só para críticas em seus desfiles. As autoridades não toleraram tamanha exposição e o Chefe de Polícia, incumbido pelos poderes públicos de autorizar os desfiles, proibiu primeiro os carros de críticas e, em meados da primeira década do século XX e até 1914, proibiu os clubes com motivos africanos (VIEIRA FILHO, 1995).

As proibições, de 1905 até 1914, podem ter sido causadas pela forma como eram vistas as populações negras, pelo grau de comprometimento com as facções liberais dos governantes e outras autoridades e o tipo de oposição feita pelos líderes e fomentadores dos Clubes Uniformizados Negros. A intolerância às manifestações negras nesse momento parece ter atingido seu mais alto grau, coincidindo com o último expurgo de radicais do liberalismo dos postos do Executivo e da política brasileira.

Nicolau Sevcenko (1983, p. 36-37) aponta essas crises políticas, desencadeadas com a proclamação da República em 1889, e as posteriores, de 1891, 1893, 1897 e a última em 1904, como responsáveis pelas: “[...] deposições, exílios e deportações [...] tendendo a eliminar da cena política os grupos comprometidos com os anseios populares mais latentes e envolvidos nas correntes mais férvidas do republicanismo."

Com as proibições das exibições de desfiles negros, os grandes clubes não desfilam, mas outros pequenos grupos ainda mantêm temáticas africanas em seus desfiles. Conforme a descrição publicada na nota Carnaval, do jornal A Bahia de 23 de fevereiro de 1908, o clube Diabos em Folia trouxe em seus préstitos: “[...] 12 africanos, originarios de Guiné, formando luzida guarda, Panella do Feitiço - ahi é que esta o dendê, onde encontra remedio para todos os Males [...]" (CARNAVAL, 1908, p. 1).

No senso comum cristão, as manifestações negras eram, e agora ainda mais com a profusão de igrejas neopentecostais, associadas ao diabólico. Sabemos da associação, no Carnaval de Salvador, da figura do diabo com os grupos de temática africanas; talvez tenha surgido daí o nome do grupo Diabos em Folia. Entretanto, o mais importante é a resistência de elementos proibidos nas ruas.

Observamos também o aparecimento de grupos com temática indígena, neste momento de proibição de temas africanos. Talvez tenha sido a estratégia de pequenos blocos para continuar existindo e saindo às ruas com adaptações em suas fantasias, que, naquele momento, em vez de representar tribos africanas, passam a representar os indígenas brasileiros.

A tradição de os negros representarem autos de inspiração e temática indígenas remonta aos tempos de Colônia, e poderia ser uma aproximação para entendermos o travestimento dos clubes uniformizados negros em clubes de temática indígena. Nos processos de catequese empreendidos pelos jesuítas, as representações com base nas lendas dos povos autóctones foram amplamente utilizadas. Assim o aprendizado destes autos deve ter sido 
transmitido de geração em geração, chegando até as brincadeiras carnavalescas do início do século XX em Salvador.

Existem vários registros dos contatos, convivência e até enovelamento das identidades de grupos indígenas e negros no sertão baiano desde os primeiros ensaios de penetração colonial no sertão (VIEIRA FILHO, 2011). Em outra pesquisa constatamos que as autoridades utilizaram os casamentos e uniões entre negros e indígenas, em consequência, o nascimento de muitas crianças mestiças, para justificar o fechamento de dissolução de Missões Franciscanas na região de Jacobina (VIEIRA FILHO, 2007).

Outra interpretação possível estaria nos terreiros de candomblé, onde os ancestrais donos da terra eram respeitados e sacralizados, assim como os trazidos da África, gestando dentro das Casas de Candomblés de Caboclo as representações que transbordariam para as agremiações carnavalescas. Os processos formativos, nesta explicação, são fundamentais para elucidarmos a transformação.

Vamos dar um pequeno salto no tempo para abordar outra forma de resistência e um processo de questionamento também importantes por envolver vários aspectos.

Atualmente, a Noite da Beleza Negra do Ilê Aiyê é uma das festas mais concorridas e é vista como um dos mais significativos eventos de afirmação dos negros soteropolitanos. Daniele Santos Santana (2018, p. 19) analisa essa ação promovida pelo bloco carnavalesco:

Um exemplo clássico dessa representatividade negra positiva que o Ilê oferece até hoje é a 'Noite da Beleza Negra'. Evento em que é escolhida a Deusa do Ébano [...] as mulheres participantes não precisavam desfilar seminuas ou serem magérrimas, como na maioria dos desfiles de moda. Neste concurso, os principais requisitos eram saber dançar as músicas do carnaval daquele ano, saber a história do Bloco e a história da África [...].

Os requisitos necessários para a escolha da Deusa de Ébano nos fazem pensar na força dos processos de autorreconhecimento e reforço da negritude elaborados desde pelo menos o I
Congresso do Negro Brasileiro, promovido pelo Teatro Experimental do Negro. No Congresso foram discutidos "[...] História, Vida Social, Sobrevivências Religiosas, Sobrevivências Folclóricas, Línguas e Estética. Cada um deles também subdividido em tópicos que aprofundavam os temas." (ROSA, 2007, p. 74).

$\mathrm{O}$ próprio Teatro Experimental do $\mathrm{Ne}$ gro promoveu concursos com as mesmas características:

Os concursos de beleza Rainha das mulatas e Boneca de pixe foram concebidos como instrumento pedagógico buscando realçar o tipo de beleza da mulher afro-brasileira e educar o gosto estético popular, pervertido pela pressão e consagração exclusiva de padrões brancos de beleza [...] (NASCIMENTO, 2004, p. 223).

Contudo, essa ideia foi lançada um pouco antes em Salvador.

A eleição de Rainhas do Carnaval é um costume bastante antigo dos Clubes da elite soteropolitana, mas no ano de 1949, no Carnaval do Quadricentenário, aconteceu um movimento marcante: a organização do concurso da Rainha Negra, movimento orquestrado pela Escola de Danças Mululu.

No jornal Diário de Notícias de 28 de janeiro de 1949, lemos o seguinte:

[...] A nota carnavalesca que está dominando a cidade é, a propalada eleição da Rainha Negra do Carnaval Bahiano de 1949 [...]. Já aquela conhecida e tradicional Escola de Danças [Mululu], vem presentear um fato que revolucionará o carnaval, dadas as suas características. (CARNAVAL, 1949, p. 1).

O próprio escritor do jornal já salienta o revolucionário fato de um concurso, naquele momento, procurar eleger uma Rainha Negra para o Carnaval. Fato também bastante instigante é o momento: ano das comemorações dos 400 anos de fundação da Cidade de Salvador. Muito mais que a inebriante beleza da escolhida, a busca de rivalizar com as elites em um momento de foco para a cidade parece muito especial na vida das populações negras.

As escolas de dança eram espaços bastante marcados na vida cotidiana da cidade, pois 
mantinham uma certa postura quanto ao ensino de uma habilidade pretensamente inata para populações negras: a dança.

\section{Algumas considerações}

A dança sempre foi um precioso bem para as populações negras soteropolitanas. Thales de Azevedo (1955, p.118), tratando das artes, assim argumentou: "[...] 0 povo tem na Bahia a sua arte própria e os artistas que a interpretam de acordo com os seus padrões. Nesse sentido existe uma arte por assim dizer particular da gente pobre e de côr, especialmente no domínio da música e da dansa."

Música e dança, nas culturas afrodescendentes, se misturam e se completam. A ausência da batida, que constitui a síncopa nas principais formas musicais afro-americanas, é preenchida pelo jogo de corpo dos dançantes. Instigado a preencher o vazio, o corpo se comunica e se liga com outros corpos, atravessam os espaços do possível e habitam, por um instante, no improvável da quase queda e do improviso. Ele também preenche o vazio provocado pelo desenraizamento, nos tempos da escravização, mostrando as formas diferentes de se locomover no espaço, mas que se encontram na umbigada. E o mais importante, transformar o que deveria ser apenas uma máquina de produção, em pura diversão e alegria (SODRÉ, 1998).

Pesquisando em momento muito próximo do movimento de escolha da Rainha Negra, Thales de Azevedo (1955, p. 171) destaca que a dança fazia parte dos momentos de sociabilidades: "[...] Uma estudante muito escura diz que dansa com qualquer rapaz, fazendo questão apenas de que êle saiba dansar bem."

Um patrimônio para os soteropolitanos e, especialmente, caro aos negros, a dança, ou o saber dançar, era muito importante para as sociabilidades. Abria as portas sociais para os jovens que, muitas vezes, utilizam suas habilidades para mostrar o quanto haviam adquirido de civilidade. Mostrando-se respeitosos, podiam ter uma chance de ouro com as moças, ou até mesmo para se inserir nas fileiras dos aceitos socialmente nos quadros das agremiações brancas. Nos parece que a boa educação incluía o aprendizado da dança de salão como uma de suas referências; e para satisfazer essa exigência formativa, organizaram-se as escolas de dança. Entretanto, dançar também ligava os jovens das "elites de cor" às tradições afro-brasileiras, e isso podia ser um problema, pois naquele momento, e para algumas pessoas dessas camadas negras da população, esse traço africanizado era "[...] mal interpretado como produto de um impulso meramente conservador, retrógrado e anacrônico. Luta e resistência - mas também, naturalmente, apropriação e expropriação" (HALL, 2003, p. 248).

Alguns dos participantes das elites negras soteropolitanas da pesquisa de Thales de Azevedo (1955, p. 169), falando de sua não participação nos clubes das elites baianas, indicam uma forma de resistência a esse impulso da dança atribuído aos negros de forma generalizada: "[...] todos estes dizem que têm um temperamento esquisito, que sempre foram muito retraidos, que não aprenderam a dansar; chegam alguns a afirmar que, mesmo lendo sido aceitos, raras vezes vão a uma festa nos clubes."

Os impulsos da dança são fortes nas comunidades negras, mas esses jovens negavam esse traço afrodescendente, tornando-se, em seu próprio ponto de vista, esquisitos. A expropriação de sua pertença às comunidades negras feita por eles mesmo nos remete à leitura de Fanon (2008, p. 95):

Se ele se encontra a tal ponto submerso pelo desejo de ser branco, é que vive em uma sociedade que torna possível seu complexo de inferioridade, em uma sociedade cuja consistência depende da manutenção desse complexo, em uma sociedade que afirma a superioridade de uma raça; é na medida exata em que esta sociedade lhe causa dificuldade que ele é colocado em uma situação neurótica.

Os jovens das elites de cor que não sabiam dançar percebem que alguma coisa estava errada com eles; mesmo tendo atingido um 
patamar econômico que lhes permitia frequentar os clubes das elites soteropolitanas, eles se isolam. Já haviam percebido as diferenças de cor e privilégios destinados aos brancos. Ao longo de sua vida, devem ter passado por muitas situações de discriminação e vivenciado o racismo no cotidiano. Contudo, não conseguem ver que o problema está na sociedade racista e não neles próprios.

Outro ponto instigante eram os nomes dessas escolas de dança. Essa fase da pesquisa está apenas em seu início, porém já é possível salientar uma postura obstinada de embate e de crítica às práticas excludentes das elites soteropolitanas, postulada por esses grupos organizados negros com base de ação partindo das escolas de dança. Além disso, toda uma logística era necessária para a organização de um concurso dessa magnitude, então uma boa parcela da comunidade negra deve ter sido mobilizada para garantir todas as etapas do Concurso e premiação da Rainha Negra de 1949, o Carnaval do Quadricentenário.

Com isso foi possível verificar a existência de uma longa experiência de resistência das populações negras em vários períodos históricos diferentes, mas sempre enfrentando as elites para conquistar e garantir seu espaço de reivindicações nas festas dedicadas ao Rei Momo ocorridas ao longo do tempo em terras soteropolitanas.

\section{REFERÊNCIAS}

AZEVEDO. Thales de. As elites de cor: um estudo de ascensão social. São Paulo: Cia. Editora Nacional, 1955.

BHABHA, Homi K. O local da cultura. Belo Horizonte: Editora da UFMG, 1998.

BUENO, Marielys Siqueira. Festa: o dom do espaço. Revista Hospitalidade, São Paulo, ano 3, n. 2, p. 91-103, 2º sem. 2006.

CARNAVAL. A Bahia, p. 1, 23 fev. 1908

CARNAVAL. Diário de Notícias, p. 1, 28 jan. 1949.

CARR. Edward H. Que é História? Rio de Janeiro: Paz e Terra, 1982.
DEBRET, Jean B. Viagem pitoresca e histórica ao Brasil. São Paulo: Martins, 1972.

FANON, Frantz. Pele negra, máscaras brancas. Salvador: EDUFBA, 2008.

HALL, Stuart. Da diáspora: identidades e mediações culturais. Belo Horizonte: Editora da UFMG, 2003.

A identidade cultural na pós-modernidade. 11. ed. Rio de Janeiro: DP \& A, 2006.

MANIFESTO Carnavalesco do Clube Uniformizado Embaixada Africana. Correio de Notícias, Salvador, p. 2, 27 fev.1897.

NASCIMENTO. Abdias do. Teatro experimental do negro: trajetórias e reflexões. Estudos Avançados, São Paulo, v. 18, n. 50, p. 209-224, jan./abr. 2004.

O CARNAVAL. Jornal de Notícias. Salvador, p. 1, 19 fev. 1898.

RECLAMAÇÕES. Telegrama de leitor. Correio de Notícias. Salvador, p. 2, 18 fev. 1898.

REDINHA, José. Subsídios para a História, Arqueologia e Etnografia dos Povos da Lunda: Campanha Etnográfica ao Tchiboco (Alto-Tchicapa), vol. I: Notas de Viagem. Lisboa: Companhia de Diamantes de Angola, 1953.

RODRIGUES, Raimundo Nina. Os africanos no Brasil. 7. ed. Brasília: Editora UnB, 1988.

ROSA, Daniela Roberta Antônio. Teatro experimental do negro: estratégia e ação. 2007. $174 \mathrm{f}$. Dissertação (Mestrado em Sociologia) - Instituto de Filosofia e Ciências Humanas da Universidade Estadual de Campinas (Unicamp), Campinas, SP, 2007.

SALVADOR. Prefeitura Municipal de Salvador. Repertório de fontes sobre a Escravidão existente no Arquivo Municipal de Salvador. As Posturas (1631/1889). Salvador: Fundação Gregório de Matos/Prefeitura Municipal de Salvador, 1988.

SANTANA, Daniele Santos. Ilê Aiyê: interações entre arte educação e cultura afro-brasileira. 2018. 162 f. Dissertação (Mestrado em Artes) - Programa de Pós-Graduação em Arte do Instituto de Artes Visuais da Universidade de Brasília (UnB). Brasília, DF, 2018.

SANTOS, Jair Ferreira dos. 0 que é pós-moderno. São Paulo: Brasiliense, 1986.

SANTOS. Josélio Teles dos. Divertimentos estrondosos: batuques e sambas no século XIX. In: SANSONE, Lívio; SANTOS, Josélio Teles do (Org.). Ritmos em trânsito: socioantropologia da música 
baiana. São Paulo: Dynamis Editorial, 1997. p. 1738.

SANTOS FILHO, Gabriel dos. 0 catolicismo brasileiro e a construção de identidades negras na contemporaneidade: um olhar socioantropológico sobre a Pastoral Afro-Brasileira. Salvador: EDUFBA, 2012.

SEVCENKO, Nicolau. Literatura como missão. 2. ed. São Paulo: Brasiliense, 1983.

SIMSON, Olga Rodrigues de Moraes Von. Espaço urbano e folguedo carnavalesco no Brasil: uma visão ao longo do tempo. Cadernos do CERU, n. 15, p. 297-305, ago. 1981.

SODRÉ, Muniz. Samba, o dono do corpo. 2. ed. Rio de Janeiro: Mauad, 1998.

SOIHET, Rachel. Reflexões sobre o carnaval na historiografia - algumas abordagens. Tempo, v. 4, n. 7, p. 1-15, 1999.

VERGER, Pierre. Procissões e carnaval no Brasil. Ensaios e Pesquisa, Salvador, n. 5, p. 1-15, out. 1980.

VIEIRA FILHO, Raphael Rodrigues. A africanização do carnaval de Salvador - a recriação do espaço carnavalesco (1876-1930). 1995. 228 f. Dissertação
(Mestrado em História) - Programa de Mestrado em História da Pontifícia Universidade Católica de São Paulo (PUC-SP), São Paulo, 1995.

Folguedos negros no carnaval de Salvador (1990-1930). In: Ritmos em trânsito: socioantropologia da música baiana. São Paulo: Dynamis Editorial, 1997.

. Contatos e solidariedades: negros e payaya no sertão de Jacobina, BA. In: SIMPÓSIO NACIONAL DE HISTÓRIA, 24., 2007, São Leopoldo, RS. Anais... São Leopoldo: Unisinos, 2007. História e multidisciplinaridade: territórios e deslocamentos. CD-ROM.

Mitos e povos no sertão das jacobinas (séculos XVI até XVIII). In: OLIVEIRA, Josivaldo Pires (Org.). Populações negras na Bahia: ensaios de história social. Curitiba: Appris, 2011. vol. 1, p. 12-26.

WILLIAMS, Raymond. Marxismo e literatura. Rio de Janeiro: Zahar, 1978.

Recebido em: 05/10/2018

Aprovado em: 02/03/2019 